\title{
Profil Ekspresi Koreseptor Human Immunodeficiency Virus CCR5 dan CXCR4 pada penderita Infeksi Human Immunodeficiency Virus yang menggunakan Narkoba Suntik
}

\author{
Agnes Rengga Indrati, ${ }^{1}$ Ida Parwati, ${ }^{1}$ Herry Garna, ${ }^{2}$ Bachti Alisjahbana ${ }^{3}$ \\ ${ }^{1}$ Departemen Patologi Klinik Fakultas Kedokteran Universitas Padjadjaran/Rumah Sakit Dr. Hasan Sadikin \\ Bandung, Indonesia, ${ }^{2}$ Departemen Ilmu Kesehatan Anak Fakultas Kedokteran Universitas Padjadjaran/Rumah \\ Sakit Dr. Hasan Sadikin Bandung, Indonesia, ${ }^{3}$ Departemen Ilmu Penyakit Dalam Fakultas Kedokteran \\ Universitas Padjadjaran/Rumah Sakit Dr. Hasan Sadikin Bandung, Indonesia
}

\begin{abstract}
Abstrak
Infeksi human immunodeficiency virus masih merupakan masalah kesehatan global, termasuk di Indonesia dan pemakai narkoba suntik merupakan populasi yang besar di antara orang dengan infeksi HIV/AIDS (ODHA) yang berperan penting dalam transmisi infeksi HIV. Opioid banyak digunakan penasun dan memengaruhi ekspresi CCR5 serta CXCR4 yang merupakan koreseptor yang digunakan oleh HIV untuk menginfeksi sel limfosit T CD4. Penelitian ini bertujuan menganalisisperbedaan ekspresi koreseptor HIV CCR5 dan CXCR4 antara ODHA penasun dan ODHA bukan pemakai narkoba. Penelitian observasional analitik dengan rancangan cross sectional ini dilaksanakan pada September 2011-Mei 2013. Subjek penelitian adalah ODHA penasun yang diikutsertakan secara consecutive sampling di RSUP Dr. Hasan Sadikin Bandung serta di komunitas di Jawa Barat. Pemeriksaan ekspresi koreseptor CCR5, CXCR4 dan jumlah sel limfosit T CD4 dilakukan dengan metode flowsitometri. Ditemukan 80 orang subjek penelitian dengan 17 orang pengguna narkoba suntik aktif, 16 orang dalam terapi metadon, 15 orang mantan penasun, dan 32 orang bukan pemakai narkoba. Persentase CXCR4 di permukaan sel limfosit T CD4 lebih tinggi bermakna pada ODHA bukan pemakai narkoba dibanding dengan ODHA penasun $(86,13 ; 78,23 ;$ p 0,001). Tidak terdapat perbedaan bermakna ekspresi CCR5 dan MFI CXCR4 di permukaan sel limfosit T CD4 antara ODHA penasun dan ODHA bukan pemakai narkoba $(p>0,05)$. Dari penelitian ini disimpulkan bahwaekspresi CXCR4 lebih tinggi pada ODHA penasun dibanding dengan ODHA bukan pemakai narkoba pada sel limfosit T CD4. Ekspresi koreseptor CXCR4 yang lebih tinggi dibanding dengan CCR5 baik pada kelompok ODHA penasun dan bukan pemakai narkoba.
\end{abstract}

Kata kunci: CCR5, CXCR4, HIV, penasun

\section{Human Immunodeficiency Virus-Coreceptors CCR5 and CXCR4 Expression Profile in Injecting Drug Users Living with HIV}

\begin{abstract}
Human immunodeficiency virus (HIV) is considered as global health problem, includingin Indonesia. A large proportion of people living with HIV/AIDS (PLHAs) are Injecting Drug Users (IDUs) who play an important role in HIV transmission. Opioid that is used by many IDUs influence the expression of CCR5 and CXCR4, which are the co-receptors used by HIV to infect CD4 T lymphocyte cells. This study aimed to compare the expression of HV CCR5 and CXCR4 co-receptors between IDU PLHAs and non-drug user PLHAs. This was a crossectional analytical observation performed in the period of September 2011-May 2013 on IDU PLHAs who were sampled consecutively in Dr. Hasan Sadikin General Hospital Bandung and community in West Java. Flowcytometry was used for analyzing CCR5 and CXCR4 co-receptors as well as the CD4 T lymphocyte count. Eighty subjects were included in the study, consisting of 17 active injecting drug users, 16 IDUs on methadone therapy, 15 former IDUs, and 32 non-drug user PLHAs. The percentage of CXCR4 on CD4 T lymphocyte surface was significantly higher in non-drug user PLHAs when compared to IDU PLHAs (86.13; 78.23; p 0.001). No significant difference was found in the expression of CCR5 and MFI CXCR4 on CD4 T lymphocyte surface between IDU PLHAs and non-drug user PLHAs ( $p>0.05)$. It is concluded that the expression of CXCR4 on CD4 T lymphocyte surface is higher in IDU PLHAs compared to non-drug user PLHAs. The expression of CXCR4 co-receptors is higher than the expression of CCR5 both in IDU PLHAs and non-drug user PLHAs.
\end{abstract}

Key words: CCR5, CXCR4, HIV, IDUs

Korespondensi: Dr. Agnes R. Indrati, dr., Sp.PK(K), M.Kes, Departemen Patologi Klinik Fakultas Kedokteran Universitas Padjadjaran/Rumah Sakit Dr. Hasan Sadikin, Jalan Pasteur No. 38 Bandung, Email: agnesariantana.sppk@gmail.com 


\section{Pendahuluan}

Infeksi human immunodeficiency virus (HIV) merupakan salah satu masalah kesehatan secara umum. Indonesia merupakan salah satu negara dengan prevalensi infeksi HIV tinggi di antara negara di Asia. Pemakaian narkoba suntik merupakan faktor risiko penting yang memengaruhi peningkatan prevalensi HIV di Indonesia. ${ }^{1,2}$ Pemakai narkoba suntik (penasun) merupakan populasi dengan risiko terinfeksi HIV 22-50 kali lebih besar daripada populasi umum. ${ }^{3}$ Peningkatan risiko ini berkaitan dengan kebiasaan bertukar jarum yangterkontaminasi antarpemakai narkoba suntik. Selain itu, pada populasi penasun perilaku seksual berisiko seperti berhubungan dengan beberapa partner seksual dan memakai pekerja seks komersial juga berkaitan dengan transmisi infeksi HIV. ${ }^{4}$ Pemakai narkoba yang terdiri atas pemakai narkoba aktif, mempergunakan terapi metadon, dan mantan penasun merupakan populasi yang berpotensi memperantarai transmisi HIV/AIDS dari kelompok yang terlokalisasi pada pengguna narkoba ke populasi umum. ${ }^{5}$

World Health Organization (WHO) dan United Nations Programme Against HIV/AIDS (UNAIDS) ${ }^{6}$ pada tahun 2008 menyatakan bahwa Indonesia merupakan salah satu negara di Asia dengan pertumbuhan kasus HIV paling cepat, dengan estimasi prevalensi $<0,1 \%$ pada tahun 2000 menjadi sekitar $0,27 \%$ pada tahun $2010 .{ }^{1}$ Data Kementrian Kesehatan Indonesia tahun 2011, pemakai narkoba suntik merupakan proporsi yang besar pada individu yang terinfeksi HIV di Indonesia, yaitu $41 \%^{7}$ dan sebagian besar di antaranya menggunakan opiat. ${ }^{8}$ Data WHO tahun 2012 menemukan sekitar 16 juta pengguna narkoba suntik di seluruh dunia dan sekitar 3 juta di antaranya telah terinfeksi HIV. ${ }^{9}$ Sampai tahun 2009 diperkirakan 333.200 orang terinfeksi HIV di Indonesia dengan 43-56\% di antaranya merupakan penasun. ${ }^{8,10}$ Iskandar dkk. $^{4,11}$ menyatakan bahwa $100 \%$ penasun di Bandung pernah menggunakan opioid seperti morfin, heroin, maupun metadon.

Progresivitas HIV berjalan lebih cepat pada kelompok penasun, keadaan ini diperkuat oleh beberapa penelitian, seperti pada penelitian Poundstone dan Moore di Amerika Serikat yang menemukan penurunan sel limfosit T CD4 yang lebih progresif pada individu HIV penasun dibanding dengan bukan penasun. Berbagai penelitian lain menemukan bahwa pemakaian narkoba suntik terutama morfin menimbulkan efek yang merugikan pada sistem imun seperti penurunan aktivitas sel natural killer (NK), efek fagosit dan kemotaksis neutrofil, serta supresi proliferasi sel $\mathrm{T}^{13}$ Pemakaian morfin ditemukanakan mempercepat progresi infeksi HIV menjadi AIDS..$^{14,15}$

Selain CD4 sebagai reseptor utama, HIV juga membutuhkan koreseptor untuk dapat menimbulkan infeksi pada sel inang. Koreseptor yang telah diidentifikasi dapat digunakan oleh HIVin vivo adalah CC-chemokine receptor 5 (CCR5) dan CX-chemokine receptor 4 (CXCR4). Sesudah terikat pada CD4 dan koreseptor, terjadi fusi antara membran sel serta virus, diikuti oleh internalisasi virus. ${ }^{16,17}$ Koreseptor CCR5 dan CXCR4 merupakan reseptor untuk kemokin dan ligan alamiah beberapa kemokin seperti MIP- $1 \alpha$, MIP- $1 \beta$, dan RANTES pada CCR5 sertaSDF-1 pada CXCR4. Ikatan antara kemokin dan reseptor akan memperantarai fungsi dan aktivitas sel termasuk perkembangan sel, pergerakan leukosit, angiogenesis, dan respons imun.Koreseptor CCR5 dan CXCR4 ditemukan pada berbagai sel seperti sel limfosit B, limfosit T, monosit, makrofag, dan sel polimorfonuklear, tetapi hanya sel-sel yang memiliki molekul CD4 dan koreseptor CCR5 atau CXCR4 memiliki risiko untuk terinfeksi HIV. ${ }^{18}$ Peningkatan ekspresi CCR5 dan CXCR4 pada sel-sel imun ditemukan pada pemberian/stimulasi opioid. Telah terjadi peningkatan ekspresi CCR5 dan CXCR4 sesudah pemberian morfin pada sel-sel imun. ${ }^{19}$

Peningkatan ekspresi kedua koreseptor ini dengan stimulasi opioid akan meningkatkan risiko infeksi dan progresivitas HIV. Dari berbagai penelitian ditemukan bahwa terdapat crosstalk antara reseptor opiod dan reseptor kemokin CCR5 serta CXCR4.Stimulasi pada reseptor opioid dapat memengaruhi ekspresi reseptor kemokin termasuk CCR5 dan juga CXCR4..$^{14,20}$ Sebaliknya, stimulasi pada reseptor kemokin menggunakan paparan antigen pada HIV-1 melalui koreseptor CCR5 atau CXCR4 dapat meningkatkan ekpresi reseptor opioid Hal ini menyebabkan crosstalk antara reseptor kemokin dan reseptor opioid dianggap merupakan penghubung sistem imun dengan sistem persarafan. ${ }^{20}$ Tujuan penelitian ini adalah melihat perbedaan ekspresi koreseptor CCR5 pada sel limfosit $T$ dan limfosit T CD4 antara ODHA penasun dan ODHA bukan pemakai narkoba.

\section{Metode}

Penelitian telah dilaksanakan sejak Oktober 2011 setelah mendapatkan persetujuan dari Komite 
Etik Penelitian Kesehatan FK Unpad Bandung. Pengambilan sampel penelitian dilaksanakan antara bulan Oktober 2012 sampai Mei 2013.

Individu dengan infeksi HIV di Klinik Teratai dan Poliklinik Terapi Rumatan Metadon RSUP Dr. Hasan Sadikin Bandung, di komunitas dibawah binaan LSM Rumah Cemara, yaitu di Bandung, Garut, Sukabumi, Bogor, Bekasi, Cibinong, dan Depok. Baik subjek penelitian maupun subjek kontrol penelitian bersedia ikut dalam penelitian sesudah diberi penjelasan mengenai penelitian dengan menandatangani persetujuannya atau informed consent. Pasien yang telah memenuhi kriteria inklusi, yaitu penderita HIV yang berusia 15-60 tahun dan belum mendapatkan terapi antiretrovirus selanjutnya dibagi menjadi dua kelompok, yaitu kelompok HIV dan penasun serta kelompok HIV bukan pemakai narkoba, lalu dilakukan pengambilan darah. Terhadap seluruh sampel pasien dilakukan pemeriksaan CD4, ekspresi CCR5, dan CXCR4.Pemeriksaan sel limfosit $\mathrm{T}$ CD4 mempergunakan prinsip pemeriksaan flowcytometry (FACSCount-Becton Dickinson) sedangkan pemeriksaan ekspresi koreseptor CCR5 dan CXCR4 menggunakan metode flowcytometry (FacsCalibur-BD/Beckton Dickinson) pada peripheral blood mononuclear cells (PBMC) dengan prinsip pemeriksaan menghitung komponen dan juga struktur sel menggunakan antibodi CD3-CD4-CCR5-CXCR4 yang telah dilabel dengan fluorokrom.
Rancangan penelitian ini adalah metode penelitian cross sectional (potong lintang) yang mengkaji perbandingan antara kelompok penasun dan bukan pemakai narkoba dilakukan dengan $t$-test bila data berdistribusi normal atau Uji Mann Whitney bila data tidak berdistribusi normal. Kemaknaan ditentukan berdasarkan nilai $\mathrm{p}<0,05$. Penelitian telah disetujui oleh Komite Etik Penelitian Kesehatan Fakultas Kedokteran Universitas Padjadjaran (No. 190/ UN6.C2.1.2/KEPK/PN/2011).

\section{Hasil}

Pada penelitian ini dilakukan analisis pada 80 orang subjek penelitian yaitu individu dengan infeksi HIV yang belum pernah menerima terapi antiretroviral dengan status pemakaian narkoba yaitu 17 orang pengguna narkoba suntik aktif, 16 orang dalam terapi metadon, 15 orang mantan penasun, dan 32 orang bukan pemakai narkoba. Kelompok ODHA penasun terdiri atas pemakai narkoba aktif dalam 30 hari terakhir, sedang menerima terapi rumatan metadon, dan mantan penasun yang sudah tidak menggunakan narkoba setidaknya 1 tahun. Karakteristik umum subjek penelitian dicatat seperti jenis kelamin, usia, jumlah sel limfosit $\mathrm{T}$ CD4, dan riwayat terapi tuberkulosis, disampaikan pada Tabel 1.

Dari hasil penelitian ini tidak ditemukan

Tabel 1 Karakteristik Umum Subjek Penelitian

\begin{tabular}{|c|c|c|c|}
\hline Karakteristik & $\begin{array}{l}\text { ODHA Penasun } \\
n=48(60 \%)\end{array}$ & $\begin{array}{c}\text { ODHA Bukan } \\
\text { Pemakai narkoba } \\
\text { n=32 }(40 \%)\end{array}$ & $\begin{array}{c}\text { Nilai Kemaknaan } \\
\text { (p) }\end{array}$ \\
\hline \multicolumn{4}{|l|}{ Jenis kelamin } \\
\hline Laki-laki & 42 & 24 & $0,127^{\mathrm{a}}$ \\
\hline Perempuan & 6 & 8 & \\
\hline \multicolumn{4}{|l|}{ Usia (tahun) } \\
\hline Rerata \pm SD & $32,7 \pm 4,2$ & $27,9 \pm 6,2$ & $0,001^{\mathrm{c}^{*}}$ \\
\hline Rentang & $24-43$ & $18-43$ & \\
\hline \multicolumn{4}{|l|}{ Jumlah sel limfosit T CD4 } \\
\hline Median & 350,79 & 288,13 & $0,120^{\mathrm{d}}$ \\
\hline Rentang & $20-1.086$ & $6-1.213$ & \\
\hline \multicolumn{4}{|l|}{ Terapi TB saat ini } \\
\hline $\mathrm{Ya}$ & 2 & 2 & $0,640^{\mathrm{b}}$ \\
\hline $\begin{array}{l}\text { Tidak } \\
\text { Riwayat terapi TB }\end{array}$ & 50 & 31 & \\
\hline $\mathrm{Ya}$ & 19 & 3 & $0,017^{\mathrm{a}^{*}}$ \\
\hline Tidak & 33 & 30 & \\
\hline
\end{tabular}

Keterangan: analisis menggunakan a ${ }^{\mathrm{a} u j i}$ chi-kuadrat, ${ }^{b}$ Uji Fisher Exact, ${ }^{\mathrm{c} U j i-t,}{ }^{\mathrm{d} U j i}$ Mann Whitney, ${ }^{*}$ bermakna jika p $<0,05$ 
perbedaan bermakna karakteristikjenis kelamin, jumlah sel limfosit T CD4, dan terapi TB pada saat ini antara kelompok studi ODHA penasun dan kelompok kontrol ODHA bukan pemakai narkoba. Ditemukan perbedaan yang bermakna usia rerata $(\mathrm{p}=0,001)$ antara kelompok penasun $(32,7 \pm 4,2)$, bukan pemakai narkoba $(27,9 \pm 6,2)$ serta riwayat terapi TB $(\mathrm{p}=0,017)$ antara ODHA penasun dan ODHA bukan pemakai narkoba.

Beberapa jenis obat/substansi dipergunakan oleh penasun dan sebagian besar menggunakan lebih dari satu macam obat dan seluruh penasun aktif mempergunakan obat dari jenis opioid, baik heroin, kodein, morfin, maupun metadon ataupun buprenorfin ilegal.

Heroin merupakan obat yang paling banyak digunakan oleh penasun aktif, sebanyak 90\% penasun aktif menggunakan heroin dan seluruh penasun aktif menggunakan satu atau lebih obat. Opioid lain yang banyak digunakan adalah morfin dan kodein (40\%) serta metadon dan juga buprenorfin ilegal (masing-masing 20\%). Seluruh penasun menggunakan satu atau lebih obat jenis opioid.

Pada ODHA bukan pemakai narkoba telah ditemukan persentase CCR5 di sel limfosit T lebih

Tabel 2 Perbandingan Ekspresi Koreseptor CCR5 dan CXCR4 antara Kelompok ODHA Penasun dan ODHA Bukan Pemakai Narkoba

\begin{tabular}{|c|c|c|c|c|}
\hline & & $\begin{array}{l}\text { ODHA Penasun } \\
n=48\end{array}$ & $\begin{array}{c}\text { ODHA Bukan } \\
\text { Pemakai Narkoba } \\
n=32\end{array}$ & $\begin{array}{c}\text { Nilai } \\
\text { Kemaknaan } \\
\text { (p) }\end{array}$ \\
\hline \multicolumn{5}{|c|}{ Sel limfosit T } \\
\hline \multirow[t]{6}{*}{ CCR5 } & Persentase & & & \\
\hline & Rerata \pm SD & $40,46 \pm 15,89$ & $49,43 \pm 19,91$ & $0,006^{c^{*}}$ \\
\hline & Rentang & $14,13-82,55$ & $22,23-87,12$ & \\
\hline & MFI T & & & \\
\hline & Median & 8,53 & 7,93 & $0,422^{\mathrm{d}}$ \\
\hline & Rentang & $5,38-12,82$ & $5,26-14,6$ & \\
\hline \multirow[t]{6}{*}{ CXCR4 } & Persentase & & & \\
\hline & Median & 65,88 & 67,57 & $0,901^{\mathrm{d}}$ \\
\hline & Rentang & $27,08-88,69$ & $31,433-96,68$ & \\
\hline & MFI & & & \\
\hline & Median & 11,0 & 12,03 & $0,045^{\mathrm{d}^{*}}$ \\
\hline & \multicolumn{4}{|c|}{ Sel limfosit T CD4 } \\
\hline \multirow[t]{7}{*}{ CCR5 } & Persentase & & & \\
\hline & Median & 32,89 & 37,85 & $0,165^{\mathrm{d}}$ \\
\hline & Rentang & $1,08-85,44$ & $15,4-89,02$ & \\
\hline & MFI & & & \\
\hline & Median & 7,64 & 6,74 & $0,076^{\mathrm{d}}$ \\
\hline & Rentang & $4,22-20,15$ & $4,14-17,07$ & \\
\hline & Persentase & & & \\
\hline \multirow[t]{5}{*}{ CXCR4 } & Median & 78,23 & 86,13 & $0,001^{\mathrm{d}^{*}}$ \\
\hline & Rentang & $47,06-92,74$ & $56,12-95,10$ & \\
\hline & MFI & & & \\
\hline & Median & 13,0 & 13,99 & $0,118^{\mathrm{d}}$ \\
\hline & Rentang & $7,29-75,35$ & $7,49-95,85$ & \\
\hline
\end{tabular}

Keterangan: analisis menggunakan ${ }^{c} u j i-t,{ }^{d}$ Uji Mann Whitney, ${ }^{*}$ bermakna jika $\mathrm{p}<0,05$; MFI: mean fluorescent density 
tinggi secara bermakna dibanding dengan ODHA penasun. Sebaliknya, dengan MFI CCR5 di sel limfosit T yang lebih tinggi pada ODHA penasun dibandingdengan ODHA bukan pemakainarkoba, walaupun perbedaan ini tidak bermakna. Densitas CXCR4 pada sel limfosit $\mathrm{T}$ (mean fluorescent Density=MFI) ditemukan lebih tinggi bermakna pada kelompok ODHA bukan pemakai narkoba dibanding dengan ODHA penasun. Demikian pula persentase CXCR4 walaupun perbedaan ini tidak bermakna. Pada sel limfosit T CD4 ODHA penasun ditemukan MFI CCR5 di sel limfosit $\mathrm{T}$, lebih tinggi dibanding dengan ODHA bukan pemakai narkoba. Sebaliknya, dengan persentase CCR5 yang ditemukan lebih tinggi pada ODHA bukan pemakai narkoba dibanding dengan ODHA penasun, walaupun perbedaan ini tidak bermakna. Persentase CXCR4 pada sel limfosit T CD4 ditemukan lebih tinggi bermakna pada ODHA bukan pemakai narkoba dibanding dengan ODHA penasun, demikian juga MFI CXCR4, walaupun perbedaan ini tidak bermakna. Perbandingan ekspresi koreseptor CCR5 dan CXCR4 di permukaan sel limfosit $\mathrm{T}$ dan sel limfosit T CD4 pada penelitian ini disampaikan pada Tabel 2.

\section{Pembahasan}

Pada penelitian ini telah ditemukan sebanyak 2 dari 52 orang kelompok penasun dan 2 dari 33 orang kelompok bukan pemakai narkoba sedang mendapatkan terapi tuberkulosis pada saat penelitian. Keadaan ini sejalan dengan penelitian Wisaksana dkk. ${ }^{12}$ di Indonesia tahun 2010 yang menemukan riwayat terapi TB pada penderita HIV penasun lebih tinggi bermakna pada penasun dibanding dengan populasi yang sama bukan pemakai narkoba ( $46,5 \%$ vs $21,5 \%$ ). Tuberkulosis merupakan infeksi oportunistik yang paling sering ditemukan pada ODHA dan infeksi HIV merupakan faktor risiko utama pada penyakit tuberkulosis. Data WHO tahun $2010^{13}$ menyatakan sekitar 24\% penasun di Indonesia merupakan penderita dengan tuberkulosis aktif. Sementara Meijerink ${ }^{14}$ menyatakan bahwa di Indonesia sebanyak $85 \%$ penderita HIV penasun berisiko terinfeksi tuberkulosis dan pemakaian narkoba suntik merupakan faktor risiko utama infeksi TB pada HIV hazard ratio 1,85 (95\% interval kepercayaan 1,28-2,67)\}. Tuberculosis meningkatkan progresivitas penyakit pada infeksi HIV dengan meningkatkan aktivasi imun dan ekspresi koreseptor CCR5 serta CXCR4 pada sel limfosit T CD4. ${ }^{16}$
Kelompok ODHA penasun terdiri atas pemakai narkoba aktif dalam 30 hari terakhir, sedang menerima terapi rumatan metadon dan mantan penasun yang sudah tidak menggunakan narkoba setidaknya 1 tahun. Karakteristik usia dan jenis kelamin kelompok penasun pada penelitian ini tidak jauh berbeda dengan yang ditemukan Iskandar $\mathrm{dkk}^{4}$ pada penelitian tahun 2010 di Bandung, yaitu usia rerata baik penasun aktif maupun mantan penasun adalah 27,8 tahun dan $92,8 \%$ penasun adalah pria.

Sebagian besar penasun aktif dan penasun dalam terapi metadon memakai lebih dari satu macam obat dan seluruh penasun aktif memakai obat dari jenis opioid, baik heroin, kodein, morfin maupun metadon ataupun buprenorfin ilegal. Hal ini sesuai dengan penelitian Iskandar ${ }^{4}$ yang menemukan seluruh penasun aktif menggunakan opioid terutama heroin, sementara morfin dan opiat lain digunakan oleh $23 \%$ penasun aktif dan metadon serta buprenorfin digunakan oleh $65 \%$ penasun aktif.

Penasun aktif dalam penelitian ini sudah menggunakan narkoba suntik dalam 30 hari terakhir sebelum wawancara dan juga dengan rerata 4,6 bulan dalam 6 bulan terakhir mereka memakai narkoba suntik. Frekuensi pemakaian narkoba suntik pada penasun aktif dalam penelitian ini adalah penggunaan narkoba suntik dengan rerata 15,8 hari dalam sebulan dan sebagian penasun menggunakan narkoba suntik pada hari saat diadakan wawancara Hasil penelitian Morineau dkk. ${ }^{15}$ pada tahun 2012 di 6 kota besar di Indonesia menemukan bahwa 32,4-33,7\% penasun aktif menggunakan narkoba suntik 1-2 kali sehari dan 39,6\% menggunakan narkoba suntik 2-3 kali dalam sebulan terakhir.

Rentang jumlah sel limfosit T CD4 pada partisipan penelitian yang cukup besar, yaitu 6-1.213 sel $/ \mathrm{mm}^{3}$ yang berarti bahwa partisipan penelitian mempunyai stadium penyakit yang berbeda-beda, walaupun seluruh partisipan penelitian belum mendapatkan ART. Jumlah sel limfosit T CD4 median, baik pada kelompok penasun maupun bukan pemakai narkoba di bawah nilai rujukan normal (nilai rujukan lakilaki: 355-1.213 sel $/ \mathrm{mm}^{3}$, perempuan: 470-1.298 $\mathrm{sel} / \mathrm{mm}^{3}$ ). Tidak ditemukan perbedaan yang bermakna jumlah sel limfosit T CD4 antara kelompok ODHA penasun dan ODHA bukan pemakai narkoba. Hal ini menunjukkan bahwa subjek penelitian dari kedua grup sedang tidak mengalami infeksi akut yang dapat memengaruhi jumlah sel limfosit CD4. Beberapa penelitian menemukan bahwa riwayat pemakaian narkoba 
suntik pada penderita HIV menurunkan jumlah sel limfosit T CD4 sekitar 33\% dalam setahun tanpa penggunaan ART, sedangkan penurunan sel limfosit pada penderita HIV bukan pemakai narkoba sekitar $22 \%$. Penurunan sel limfosit T CD4 pada ODHA penasun dalam 2 tahun adalah $66 \%$, sementara pada ODHA bukan pemakai narkoba $40 \%{ }^{7}$

Pada partisipan penelitian juga ditemukan perbedaan karakteristik usia antara ODHA kelompok penasun dan ODHA bukan pemakai narkoba. Peningkatan usia juga merupakanfaktor risiko penting terhadap progresivitas penyakit pada infeksi HIV yang terlihat dari penurunan jumlah sel limfosit T CD $4 .{ }^{17}$ Karena penjelasan di atas maka dalam analisis statistik mengenai koreseptor CCR5 dan CXCR4 dalam penelitian ini, jumlah sel limfosit T CD4 diperhitungkan sebagai faktor perancu.

Ekspresi koreseptor CCR5 dan CXCR4 dapat dilihat dari persentase sel yang mengeskpresikan koreseptor pada permukaan selnya dan juga densitas koreseptor pada setiap sel limfosit $\mathrm{T}$ dan sel limfosit T CD4. Ekspresi koreseptor CCR5 dan CXCR4 dilihat pada sel limfosit T (CD3+) maupun sel limfosit T CD4 melalui persentase sel yang mengekspresikan koreseptor ini serta densitas koreseptor pada tiap-tiap sel. Pada penelitian ini juga ditemukan ekspresi koreseptor CXCR4 yang lebih tinggi dibanding dengan koreseptor CCR5. Hal ini sejalan dengan hasil penelitian Indrati $\mathrm{dkk}^{18}$ pada orang sehat maupun pada pasien dengan infeksi $\mathrm{HIV}^{20}$ Koreseptor CCR5 merupakan reseptor utama HIV-1 pada awal infeksi, sementara pemakaian CXCR4 sering kali ditemukan pada tahap akhir penyakit dan dihubungkan dengan penurunan sel limfosit $\mathrm{T}$ CD4 yang lebih drastis. ${ }^{17}$

Ekspresi koreseptor CCR5 dan CXCR4 pada penelitian ini ditemukan lebih tinggi pada partisipan penelitian dibanding dengan kultur sel limfosit maupun PBMC orang sehat seperti yang dilaporkan Indrati dkk. ${ }^{18}$ Ekspresi persentase dan MFI CCR5 rerata yang ditemukan pada sel limfosit T CD4 orang sehat pada penelitian Indrati dkk. ${ }^{18}$ adalah 1,05 dan 3,09; sementara pada ODHA penelitian ini adalah 39,09 dan 8,21. Persentase dan MFI CXCR4 pada sel limfosit $\mathrm{T}$ CD4 orang sehat adalah 75,65 dan 5,79; yang lebih rendah daripada yang ditemukan pada ODHA penelitian ini, yaitu 79,81 dan 18,52. Peningkatan ekspresi CCR5 dan CXCR4 ditemukan pada berbagai keadaan termasuk infeksi oleh HIV dan pemakaian narkoba seperti yang didapatkan pada partisipan penelitian ini.

Pada penelitian ini ditemukan persentase ekspresi koreseptor CCR5 rerata pada sel limfosit $\mathrm{T}$ lebih tinggi secara bermakna pada ODHA bukan pemakai narkoba bila dibanding dengan ODHA penasun. Sebaliknya, pada penelitian ini ditemukan MFI CCR5 pada sel limfosit $\mathrm{T}$ dan sel limfosit T CD4 yang lebih tinggi pada ODHA penasun dibanding dengan ODHA bukan pemakai narkoba, walaupun hasil ini tidak bermakna secara statistik.

Ekspresi koreseptor CXCR4 di sel limfosit $\mathrm{T}$ CD4 ditemukan pula lebih tinggi secara bermakna pada ODHA bukan pemakai narkoba dibanding dengan ODHA penasun, demikian pula ekspresi koreseptor CXCR4 di sel limfosit $\mathrm{T}$ yang ditemukan lebih tinggi pada ODHA bukan pemakai narkoba bila dibanding dengan ODHA penasun, walaupun perbedaan ini tidak bermakna.

Beberapa publikasi telah menemukan dengan stimulasi opioid maupun agonis spesifik pada MOR akan meningkatkan ekspresi koreseptor baik CCR5 maupun CXCR4. ${ }^{14}$ Ditemukan crosstalk antara reseptor opioid dan reseptor kemokin yang dikarenakan desensitasi heterolog antara kedua jenis reseptor. ${ }^{19}$ Pada proses in vivo, lingkungan ekstraseluler yang berisi berbagai protein, ion-ion, gula, serta metabolit turut memengaruhi fungsi selular dan koordinasi sel dalam jaringan.

Pada partisipan penelitian ODHA penasun ditemukan penggunaan berbagai jenis dari narkoba dan sebagian besar ODHA penasun menggunakan lebih dari satu jenis narkoba. Penggunaan berbagai jenis narkoba tersebut dapat memicu proses sensitasi dan desensitasi heterolog karena stimulasi dari berbagai reseptor. Buprenorfin yang digunakan oleh 7/45 (13\%) partisipan diketahui bekerja melalui kappa opioid receptor (KOR) dan aktivasi KOR menginduksi respons anti-inflamasi dengan menurunkan produksi beberapa sitokin, kemokin, dan ekspresi reseptor kemokin seperti CXCR4. Selain itu, ganja atau kanabis yang digunakan oleh 19/52 (36\%) partisipan, bekerja melalui delta opioid receptor (DOR) menginduksi desensitasi heterolog yang dapat menginhibisi ekspresi reseptor kemokin seperti CCR5 dan CXCR $4 .{ }^{20}$ Paparan jangka panjang pada MOR menyebabkan adaptasi terhadap reseptor dan menyebabkan proses desensitisasi homolog dengan aktivasi diacyglicerol dan protein kinase C. ${ }^{20}$ Proses desensitasi homolog melalui MOR yang terjadi akibat pemakaian opioid dalam jangka panjang serta desensitasi heterolog melalui KOR serta DOR karena pemakaian obat lain serta sinyal yang terjadi in vivo merupakan 
penjelasan yang dapat memungkinkan ekspresi koreseptor CCR5 dan CXCR4 yang lebih rendah pada ODHA penasun dibanding dengan ODHA bukan pemakai narkoba pada penelitian ini.

Berbagaifaktor diketahuidapatmeningkatkan ekspresi CXCR4 pada sel seperti infeksi, stres oksidatif, virus, sitokin proinflamasi, serta infeksi virus dan bakteri. Berbagai infeksi seperti infeksi bakteri Staphylococcus sp, tuberkulosis, serta infeksi virus lain misalnya hepatitis B dan hepatitis $\mathrm{C}^{15}$ diketahui dapat menstimulasi ekspresi CCR5 dan CXCR4. Faktor-faktor ini sulit dihindari pada penelitian in vivo.

Pada penelitian ini persentase CXCR4 pada sellimfosit T CD4 merupakan parameter yang ditemukan lebih tinggi secara bermakna pada ODHA bukan pemakai narkoba bila dibanding dengan ODHA penasun, serta merupakan parameter yang dipengaruhi status penasun. Pada beberapa penelitian in vitro ditemukan bahwa stimulasi MOR dengan opioid atau agonis spesifik akan meningkatkan ekspresi CXCR $4,{ }^{19}$ walaupun Sengupta dkk. ${ }^{20}$ menemukan bahwa secara in vivo pada sel neuron dan in vitro CXCR4 penggunaan morfin dalam jangka panjang memengaruhi resensitasi dan juga mekanisme internalisasi reseptoryang akan berdampak pada regulasi sinyal intraseluler. Partisipan ODHA penasun aktif pada penelitian ini telah memakai narkoba suntik selama 15,3 tahun rerata 8-21 tahun. Paparan dalam jangka panjang terhadap MOR menginduksi proses desensitisasi. ${ }^{20}$

Pada penelitian ini ditemukan beberapa keterbatasan, yaitu tidak seimbangnya jumlah partisipan subjek penelitian dengan subjek kontrol serta kurang homogennya sampel penelitian pada karakteristik umum seperti distribusi usia antara kelompok ODHA penasun dan ODHA bukan pemakai narkoba. Hal ini disebabkan kesulitan dalam mencari partisipan penelitian serta menyesuaikan karakteristik partisipan penelitian antara kelompok ODHA penasun dan ODHA bukan pemakai narkoba. Terdapat keterbatasan pada penelitian ini, yaitu bervariasinya tahap penyakit pada partisipan penelitian yang terlihat dari rentang jumlah sel limfosit T CD4 yang besar pada partisipan penelitian. Jumlah sel limfosit T CD4 berkaitan dengan respons imun yang terjadi yang akan berpengaruh pula pada ekspresi CCR5 dan CXCR4.

Simpulan penelitian ini adalah ditemukan perbedaan ekspresi koreseptor CCR5 dan CXCR4 pada ODHA penasun dibanding dengan ODHA bukan penasun. Ditemukan ekspresi koreseptor baik CCR5 dan CXCR4 pada sel limfosit T CD4 pada ODHA penasun lebih rendah dibanding dengan ODHA bukan pemakai narkoba. Hal ini harus menjadi pertimbangan mengenai risiko transmisi dan perjalanan penyakit pada infeksi HIV pada kelompok penasun dan bukan penasun.

\section{Daftar Pustaka}

1. Indonesian National AIDS Commission. Republic of Indonesia Country Report on the Follow Up to the Declaration of Commitment on HIV/AIDS (UNGASS) Reporting Period 2010-2011. Jakarta; 2012.

2. Strathdee SA, Stockman JK. Epidemiology of HIV among injecting and non-injecting drug users: current trends and implications for interventions. Curr HIV/AIDS Rep. Springer; 2010;7(2):99-106.

3. Joint United Nations Programme on HIV/ AIDS. Global report: UNAIDS report on the global AIDS epidemic 2010. UNAIDS; 2010.

4. Iskandar S, Basar D, Hidayat $\mathrm{T}$, Siregar IMP, Pinxten L, van Crevel R, dkk. High risk behavior for HIV transmission among former injecting drug users: a survey from Indonesia. BMC Public Health BioMed Central. 2010;10(1):472.

5. Ministry of Health Republic of Indonesia. Integrated Biological and Behavioural Surveillance (IBBS) 2011. Jakarta: Ministry of Health Republic of Indonesia; 2011.

6. Indonesian National AIDS Commission. Republic of Indonesia Country Report on the Follow Up to the Declaration of Commitment on HIV/AIDS (UNGASS) Reporting Period 2008-2009. Jakarta; 2009.

7. Joint United Nations Programme on HIV/ AIDS. Global Report 2012: UNAIDS Report on the Global AIDS Epidemic. United Nations.; 2012.

8. Iskandar S, van Crevel R, Siregar IMP, Achmad $\mathrm{TH}$, der Ven A, De Jong CAJ. Prevention and treatment of HIV addicted patients: A biopsychosocial approach. Addict Dis. 2009;7(8):10-1.

9. Greene W. Molecular biology of HIV: implications for new therapies. In: Volberding P, Lange J, Greene W, editors. Global HIV/AIDS medicine. Edisi ke-1. China: Elsevier; 2008. hlm. 23-38.

10. Alkhatib G. The biology of CCR5 and CXCR4. Curr Opin HIV AIDS. NIH Public Access. 2009;4(2):96.

11. Burbassi S, Aloyo VJ, Simansky KJ, Meucci 0 . GTP $\gamma S$ Incorporation in the rat brain: a 
study on $\mu$-opioid receptors and CXCR4. J Neuroimmune Pharmacol. 2008;3(1):26-34.

12. Wisaksana $\mathrm{R}$, Indrati $\mathrm{AK}$, Fibriani $\mathrm{A}$, Rogayah E, Sudjana P, Djajakusumah TS, dkk. Response to first-line antiretroviral treatment among human immunodeficiency virus-infected patients with and without a history of injecting drug use in Indonesia. Addiction. 2010;105(6):1055-61.

13. World Health Organization. ATLAS of Substance Use Disorders Resources for the Prevention and Treatment of Substance Use Disorders (SUD) Country Profile: Indonesia. Jakarta: World Health Organization; 2010.

14. Meijerink $H$. Injecting drug use as a risk factor for TB among HIV-infected patients in Indonesia. 42 ${ }^{\text {nd }}$ Union World Lung Health Conference. Lille, France; 2011.

15. Morineau G, Bollen LJM, Syafitri RI, Nurjannah N, Mustikawati DE, Magnani R. HIV prevalence and risk behaviours among injecting drug users in six indonesian cities implications for future HIV prevention programs. Harm Reduct J. 2012;9(1):37.

16. Meijerink $H$, Wisaksana $R$, Iskandar $S$, Heijer
M, Ven AJAM, Alisjahbana B, dkk. Injecting drug use is associated with a more rapid CD4 cell decline among treatment naive HIVpositive patients in Indonesia. J Int AIDS Soc. 2014;17:18844.

17. De Boer RJ. Time scales of CD4+ T cell depletion in HIV infection. PLoS Med. 2007;4(5):e193.

18. Indrati AR, Meijerink $H$, Garna $H$, Alisjahbana B, Parwati I, van Crevel R, dkk. Ekspresi koreseptor human immunodeficiency virus CCR5 dan CXCR4 pada subset sel limfosit $\mathrm{T}$ serta monosit. Indones J Clin Pathol Med Lab. 2016;18(2):129-33.

19. Finley MJ, Chen X, Bardi G, Davey P, Geller EB, Zhang L, dkk. Bi-directional heterologous desensitization between the major HIV-1 co-receptor CXCR4 and the opioid receptor. J Neuroimmunol. 2008;197(2):114-23.

20. Sengupta R, Burbassi S, Shimizu S, Cappello $\mathrm{S}$, Vallee RB, Rubin JB, dkk. Morphine increases brain levels of ferritin heavy chain leading to inhibition of CXCR4-mediated survival signaling in neurons. J Neurosci. Soc Neuroscience; 2009;29(8):2534-44. 